\title{
РАЗВИТИЕ СИСТЕМЫ РЕГЛАМЕНТАЦИИ УЧЕТА НА НАЦИОНАЛЬНОМ УРОВНЕ
}

\author{
(C) 2021 Петрова О.А. \\ старший преподаватель Департамента бизнес-аналитики \\ Финансовый университет при Правительстве Российской Федерации, Россия, Москва \\ E-mail: olga1717@bk.ru
}

В последние годы система регламентации учета на национальном уровне претерпевает значительные изменения посредством издания новых нормативно-правовых актов и изменения и дополнения выпущенных ранее нормативных документов. Существенное влияние на процессы регулирования бухгалтерского учета на национальном уровне оказывает мировая практика реформирования бухгалтерского учета и отчетности, изменения мировой экономической и финансовой конъюнктуры рынка.

Ключевые слова: учет, анализ, аудит, налогообложение, регламент, национальный уровень

В последние годы система регламентации учета на национальном уровне претерпевает значительные изменения посредством издания новых нормативно-правовых актов и изменения и дополнения выпущенных ранее нормативных документов. Существенное влияние на процессы регулирования бухгалтерского учета на национальном уровне оказывает мировая практика реформирования бухгалтерского учета и отчетности, изменения мировой экономической и финансовой конъюнктуры рынка.

Стоит отметить, что на сегодняшний день роль государства в регулировании бухгалтерского учета стабильно снижается, и все большую роль в разработке регулирующих нормативноправовых актов (национальных стандартов, инструкций, пояснений, методических рекомендаций и т.д.) играют общественные профессиональные организации.

Также значительное влияние на реформирование национальных систем учета оказывают международные стандарты, которые задают необходимый вектор развития для национальных регуляторов. Как и во всех сферах экономики, области регламентации бухгалтерского учета и отчетности характерны процессы глобализации и унификации.

На сегодняшний день в мире существует множество национальных моделей бухгалтерского учета, каждая из которых имеет свои особенности. Однако все эти модели базируются на общих принципах, объединив которые можно выделить типовые модели бухгалтерского учета.

\section{К ним относятся:}

1. Британо-американская модель (Великобритания, Голландия, США). Основа данной модели - ориентация учетной политики на потребности текущих и потенциальных инвесторов и кредиторов.

2. Континентальная модель (большинство стран ЕС, Япония, Россия, франкоязычные африканские страны). Бухгалтерский учет регулируется законодательно, отличается от Британо-американской модели значительной консервативностью. Бизнес обслуживается преимущественно банками, приоритет перемещен от потребностей кредиторов и инвесторов к исполнению требований правительства (в отношении налогообложения).

3. Южноамериканская модель (Аргентина, Боливия и др.). Во многом схожа с предыдущей моделью бухгалтерского учета, но учетные данные перманентно корректируются на уровень инфляции (в связи с ее зачастую высоким уровнем). Система учета ориентирована на удовлетворение потребностей государственных плановых органов, методики учета в большей степени унифицированы.

4. Интернациональная модель - новая модель, которая в наши дни получает все большее развитие. Ее появление вызвано необходимостью в международной согласованности учета, прежде всего в интересах МНК и иностранных участников международных валютных рынков. В связи с увеличением объема иностранного инвестирования, расширением внешней тор- 
говли возникает потребность в гармонизации национальных стандартов бухгалтерского учета, что и обеспечивают международные стандарты (IFRS, GAAP, IAS и др.), созданные в рамках интернациональной модели.

Страны используют Международные стандарты финансовой отчетности (МСФО) в нескольких формах [6]:

- Использование МСФО в качестве национальных стандартов;

- Применение МСФО в качестве национальных стандартов. Для вопросов, не затронутых международными стандартами, разрабатываются национальные стандарты (Малайзия, Папуа-Новая Гвинея);

- Национальные стандарты основаны на МСФО, некоторые стандарты более детализированы, чем МСФО (Бразилия, Индия, Мексика, Норвегия, Португалия, Сингапур, Турция, Франция, Швейцария);

- Использование МСФО в качестве национальных стандартов, при необходимости их модификация в соответствии с национальными особенностями (Албания, Зимбабве, Кения, Польша, Таиланд, Ямайка);

- Национальные стандарты основаны на МСФО, за исключением того, что каждый национальный стандарт включает в себя положение, сравнивающее национальный стандарт с МСФО (Австрия, Дания, Италия, Швеция, Югославия).

Таким образом, разработка положений по бухгалтерскому учету должна сопровождаться разработкой соответствующих пояснений и инструкций, основной целью которых является унификация учетных процессов на национальном уровне. Также важно по возможности гармонизировать национальные принципы бухгалтерского учета и финансовой отчетности с принципами, применяемыми в странах, которые являются потенциальными и реальными инвесторами, кредиторами, партнерами по внешней торговле для успешного функциони- рования и развития национальной экономики в целом.

Целью нормативно-правового регулирования в целом является обеспечение стабильности функционирования и развития системы бухгалтерского учета и финансовой отчетности. Это гарантирует создание приемлемых условий последовательного, полезного, рационального и успешного выполнения системой бухгалтерского учета присущих ей функций в определенной экономической конъюнктуре.

Несмотря на то, что учетные модели имеют свои индивидуальные особенности, отличающие их от всех остальных моделей, в настоящее время все больше прослеживаются тенденции их гармонизации на фоне общих процессов глобализации и унификации.

Все вышесказанное дает возможность предположить, что в ближайшем будущем национальные стандарты бухгалтерского учета и отчетности будут максимально приближены к международным стандартам, используемым в конкретном государстве. Это вызвано расширением внешних торговых связей, необходимостью в привлечении иностранных инвестиций и кредиторов.

Регламентация национальных стандартов бухгалтерского учета в Российской Федерации осуществляется по четырехуровневой системе: законодательный, нормативный, методический и организационный уровень (по уменьшению объема регулирования). Каждый из этих уровней необходим для обеспечения стабильности функционирования и развития системы бухгалтерского учета и финансовой отчетности.

Внедрение международных стандартов финансовой отчетности в России приведет к совершенствованию и реформированию действующей системы бухгалтерского учета на всех его уровнях. Целесообразность перехода на МСФО, по мнению автора, очевидна.

\section{Библиографический список}

1. Конституция Российской Федерации (принята всенародным голосованием 12.12.1993) (с учетом поправок, внесенных Законами РФ о поправках к Конституции РФ от 30.12.2008 № 6-ФКЗ, от 30.12.2008 № 7-ФК3, от 05.02.2014 № 2-ФКЗ, от 21.07.2014 № 11-ФКЗ).

2. Федеральный закон «О бухгалтерском учете» от 06.12.2011 N 402-ФЗ.

3. Приказ Минфина РФ от 31.10.2000 № 94н (ред. от 08.11.2010) «Об утверждении Плана счетов бухгалтерского учета финансово-хозяйственной деятельности организаций и Инструкции по его применению».

4. Бабаев Ю.А. Бухгалтерский учет: учебник для вузов/ Бабаев Ю.А., Бобошко В.И., Дятлова А. Ф. - Москва: ЮНИТИ-ДАНА, 2018. - 611 с. 
5. Бычкова С. М. Бухгалтерский учет и анализ/ Бычкова С. М. - Санкт-Петербург: Питер, 2018. - 524 с.

6. Вахрушина М.А. Международные стандарты финансовой отчетности/ Вахрушина М.А. - Москва: Национальное образование, 2014. -655 .

7. Ковалев А. В. Проверки надзорных органов/ Ковалев А. В. - Ростов-на-Дону: Феникс, 2015. - 171 с.

8. Поленова С. Н. Бухгалтерский учет и отчетность: учебник для бакалавров / Поленова С. Н. - Москва: ИТК Дашков и К, 2018. - 402 с.

9. Рубцов И. В. Анализ финансовой отчетности/ Рубцов И. В. - Москва: ЮНИТИ-ДАНА, 2018-127 с.

10. Справочно-правовая система Консультант Плюс. - Режим доступа: http://www.consultant.ru/

11. Зубова Т. И. Система нормативно-правового регулирования бухгалтерского учета в Российской Федерации/ Зубова Т. И.// Экономика и социум. - 2016. - № 6(25). 